\title{
GRAVITY MEASUREMENTS ON THE DEVON ISLAND ICE GAP AND AN ADJOINING GLACIER
}

\author{
By R. D. Hyndman
}

(Department of Geophysics, The Australian National University, Canberra, A.C.T., Australia)

\begin{abstract}
Gravity measurements have been used to determine ice thicknesses across the western part of the Devon Island ice cap in the Canadian Arctic. A detailed profile of the ice-cap edge and a profile across an adjoining glacier are also given. The ice cap has been found to have a largely rock core with ice thicknesses generally less than $500 \mathrm{~m}$. A deep valley has been found in the bedrock beneath the ice cap some ${ }_{1} 5 \mathrm{~km}$. from the start of a draining glacier. The measured depths on the ice cap should be within i 5 per cent and those on the glacier within 20 per cent of the true values.
\end{abstract}

RÉsumé. Mesures gravimétriques sur la calotte de glace de l'Ile Devon el d'un glacier effluent. Des mesures gravimétriques ont été utilisées pour déterminer l'épaisseur de la partie ouest de la calotte de glace de l'Ile Devon dans l'Arctique Canadien. On ajoute un profil détaillé du bord de la calotte et un profil à travers un glacier effluent. Les résultats montrent que la calotte de glace, reposant sur un large noyau rocheux, a une épaisseur inférieure à $500 \mathrm{~m}$. On a trouvé une profonde vallée dans le socle rocheux sous la calotte à $\mathrm{I} 5 \mathrm{~km}$ environ de l'origine d'un glacier de drainage. La précision des mesures d'épaisseur est de $15 \%$ pour la calotte et de $20 \%$ pour le glacier.

Zusammenfassung. Schwerkraftmessungen auf der Eishaube von Devon Island und auf einem benachbarten Gletscher. Zur Bestimmung von Eisdicken im westlichen Teil der Eishaube auf Devon Island in der kanadischen Arktis wurden Schwerkraftmessungen herangezogen. Die Messungen erstreckten sich auch auf ein Profil am Rande der Eishaube und auf ein Profil über einen benachbarten Gletscher. Es liess sich feststellen, dass die Eishaube grossenteils einen Felskern besitzt, über dem die Eisdicke im allgemeinen weniger als $500 \mathrm{~m}$ beträgt. Im Felsuntergrund der Eishaube wurde $15 \mathrm{~km}$ hinter dem Anfang eines Abflussgletschers ein tiefes Tal entdeckt. Die gemessenen Eisdicken dürften auf der Eishaube etwa $15 \%$, auf dem Gletscher etwa $20 \%$ genau sein.

\section{INTRODUCTION}

During the summer of 1962, as part of the Arctic Institute of North America's Devon Island Expedition to the Canadian Arctic, gravity traverses were made on the western end of the Devon Island ice cap to determine ice thicknesses and bedrock topography. The profile locations are given in Figure I. The major survey was of 57 stations along an $80 \mathrm{~km}$. traverse in a north-south direction from near Sverdrup Glacier to the vicinity of Crocker Bay (A-B-C), with a $15 \mathrm{~km}$. branch of 9 stations east to near the highest part of the ice cap (B-D). In addition, a detailed $0.5 \mathrm{~km}$. traverse of 26 stations $(\mathrm{G}-\mathrm{H})$ was run in from the north-western edge of the ice cap and a profile of seven stations run across Sverdrup Glacier $(\mathrm{E}-\mathrm{F})$. The readings on the ice cap were tied in with the Dominion Observatory of Canada's Arctic gravity network.

\section{Field Procedure}

The survey technique on the main traverse involved triangulation with a Wild T2 theodolite and a Wild $2 \mathrm{~m}$. subtense bar. At each station, the subtense bar was set out at a distance of about $100 \mathrm{~m}$. at right-angles to the traverse direction. This distance was then used as the known side of the triangle including the occupied station, the previous (or subsequent) station and the subtense bar. With the subtense at each station, two determinations of the distance and elevation difference between stations were made. This provided both a check on the results and a partial cancellation of any refraction error that might be expected from long sights close to the ice surface. The distances were found to be in agreement to about $\mathrm{I}$ in $\mathrm{I}, 500$ and the elevations to $\pm 0 \cdot \mathrm{I}_{5} \mathrm{~m}$. $/ \mathrm{km}$. of traverse. This implies an error in elevation of about $6 \mathrm{~m}$. in the middle of the traverse. Difficult surveying conditions reduced the accuracy for the southern $20 \mathrm{~km}$. to about $\mathrm{I}$ in 500 for the horizontal and $\pm 0.3 \mathrm{~m}$. $/ \mathrm{km}$. of traverse in the vertical. Station intervals were about $\mathrm{I} \cdot 5 \mathrm{~km}$. 
Absolute elevations were determined by mercury barometer differences between the base station at the north coast and the ice-cap station. These could only be determined to $\pm \mathrm{I} 0 \mathrm{~m}$. but it in no way affects the computed ice thicknesses which require only elevation differences.

The edge detail consisted of 26 stations at $40 \mathrm{~m}$. intervals. A Wild theodolite and stadia rod gave elevations to within $\pm 0.3 \mathrm{~m}$. $/$ roo m. of traverse.

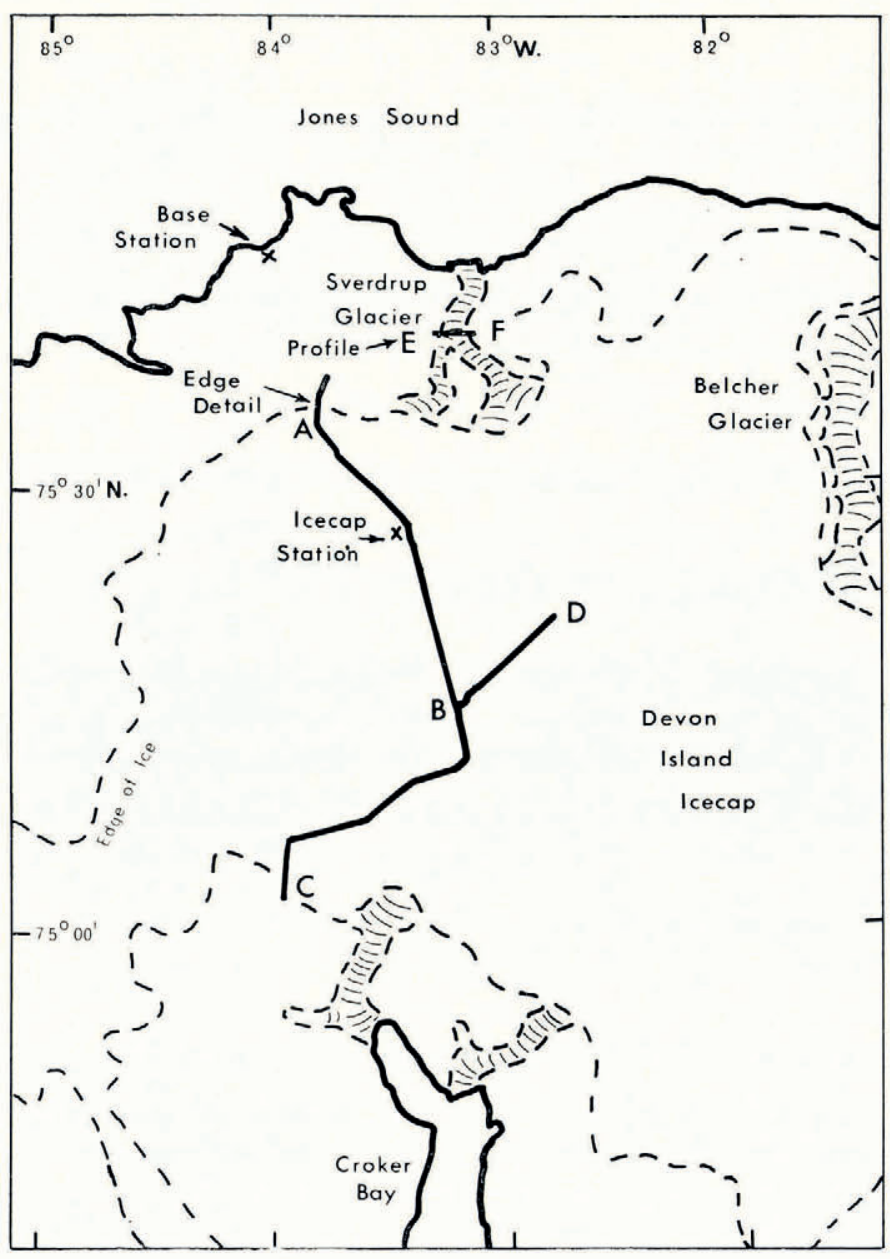

Fig. I. Location map. Profile $G-H$ is immediately west of $A$

The relative elevations for the stations on Sverdrup Glacier were determined with theodolite and levelling rod. They should be within $\pm 5 \mathrm{~cm}$. The station positions were determined by resection to previously established signals (Wyness, unpublished).

At several points along the ice-cap traverse, latitude and bearings were determined by sun-shots in order to locate the position of the traverse and to provide for latitude corrections to the gravity readings. Bearings should be within $\pm \mathrm{I} \cdot \mathrm{o}$ min. and latitudes within $\pm 0 \cdot 2 \mathrm{~min}$. of latitude.

The gravity measurements were made with Worden gravimeter No. 35 which was on loan from the Geophysics Laboratory, University of British Columbia. The meter calibration 
supplied by the manufacturer was $0.4187 \mathrm{mgal}$./scale division. A rough check on this value was provided by a comparison with gravity differences determined by the Dominion Observatory and by a short gravity network at the University of British Columbia. Since both checks agreed to within 0.5 per cent., this calibration was accepted. The instrument drift was found to be less than $0.05 \mathrm{mgal}$. $/ \mathrm{hr}$. Readings were made at stations in groups of four or more with a return to a reference within several hours in order to estimate the effect of Earth tides and instrument drift. No looping was attempted. The range of the instrument was just sufficient to complete the survey without change of the coarse adjustment.

\section{Reduction of the Observations}

I. Ice cap

The gravity method of determining the thickness of glacial ice utilizes the large difference in density and thus gravitational attraction between the ice and the underlying rock. The difference in the Bouguer gravity for a station on the ice cap from a reference off the edge of the ice is due to the difference in height of the rock floor above or below the reference station.

It should be noted that in this depth computation the ice must be assumed to approximate an infinite level sheet. The rock topography beneath the ice thus may be determined only to the extent that its features are large compared with the ice thickness. Small sharp features are smoothed out to be indistinguishable from those that are larger but with less relief.

A second assumption of this method is that there are no undetermined regional changes in gravity due to deep crustal influences and changes in near-surface rock densities. Regional gradients may only be estimated from the Bouguer gravity values at stations off the ice cap. A linear gradient was assumed between the five reference stations in this survey.

No topographic corrections were required on the relatively gentle slopes of the ice cap except for the detailed north edge survey. Cylindrical zone charts were used in the correction for this part. Small corrections were also applied to several of the off ice-cap control stations. The final profiles are shown in Figures 2 and 3 .

\section{Glacier}

The reduction of the glacier gravity profile was undertaken by considering the glacier as a body of some density contrast in the manner used in geophysical prospecting. First, terrain corrections were made for the steep valley walls using the formula of Russell and others (1960) for a semi-infinite plateau with a vertical face, and adding the effect of the small triangular section required to make up an approximate profile of the valley walls. A two-dimensional structure is assumed. The corrections were based on the heights and inclinations of the valley walls determined from survey signals of Wyness (unpublished) and estimates of P. Cress (personal communication). Secondly, small free-air and Bouguer corrections were made.

The problem is then to determine the outline of the ice profile given the Bouguer gravity values on the ice. No off-glacier references were available because of the very steep walls of the glacial valley and the roughness of the surrounding country. It is necessary therefore to estimate the influence of the glacier at its edges and then to add this value to the relative Bouguer values across the glacier. A value was calculated from an approximate profile until the shape of the glacier had been determined, at which time a new value was computed. The calculation of the glacier cross-section was then repeated.

The depths of ice at the stations across the profile were calculated by an iteration procedure by which an approximate profile is chosen and the Bouguer gravity to be expected from it calculated at each station. The approximate depths are then corrected by a factor given by the ratio of the actually observed gravity to the computed value. The procedure was repeated for each new approximation. Since the Bouguer gravity at each station is for the greater part 


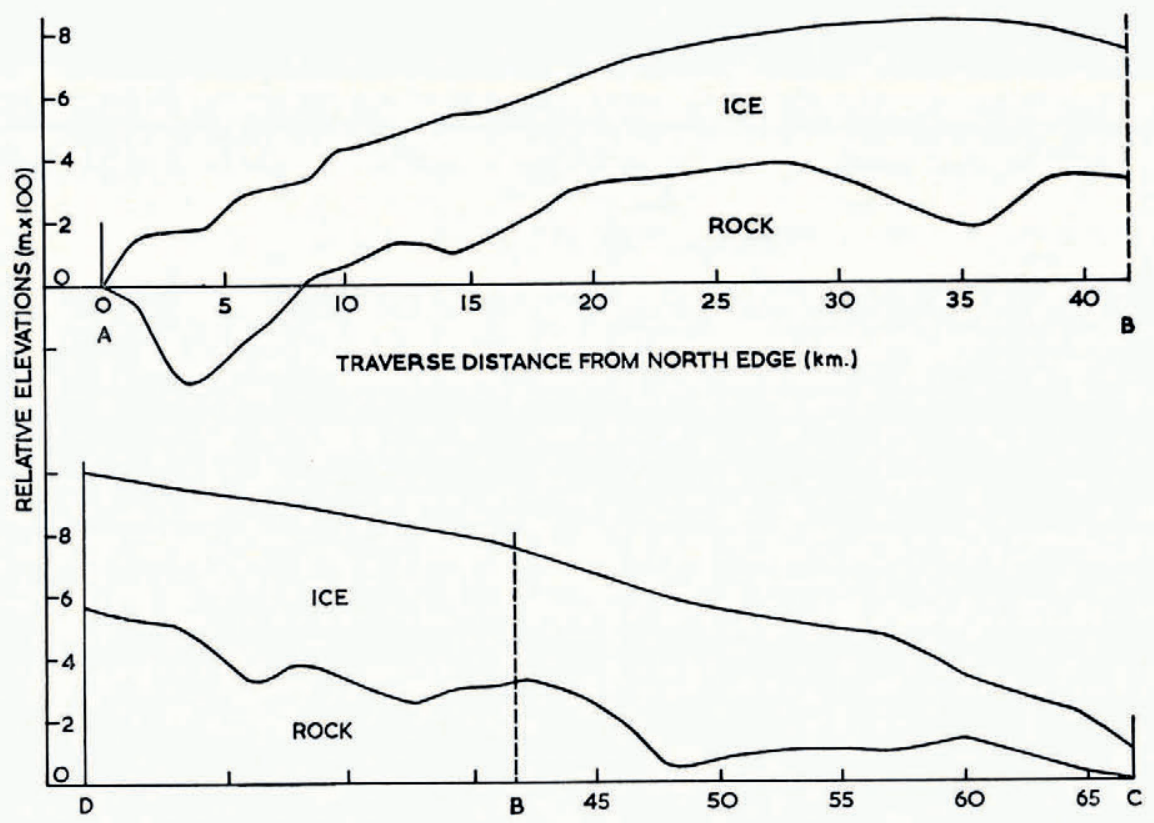

Fig. 2. Ice-cap profiles

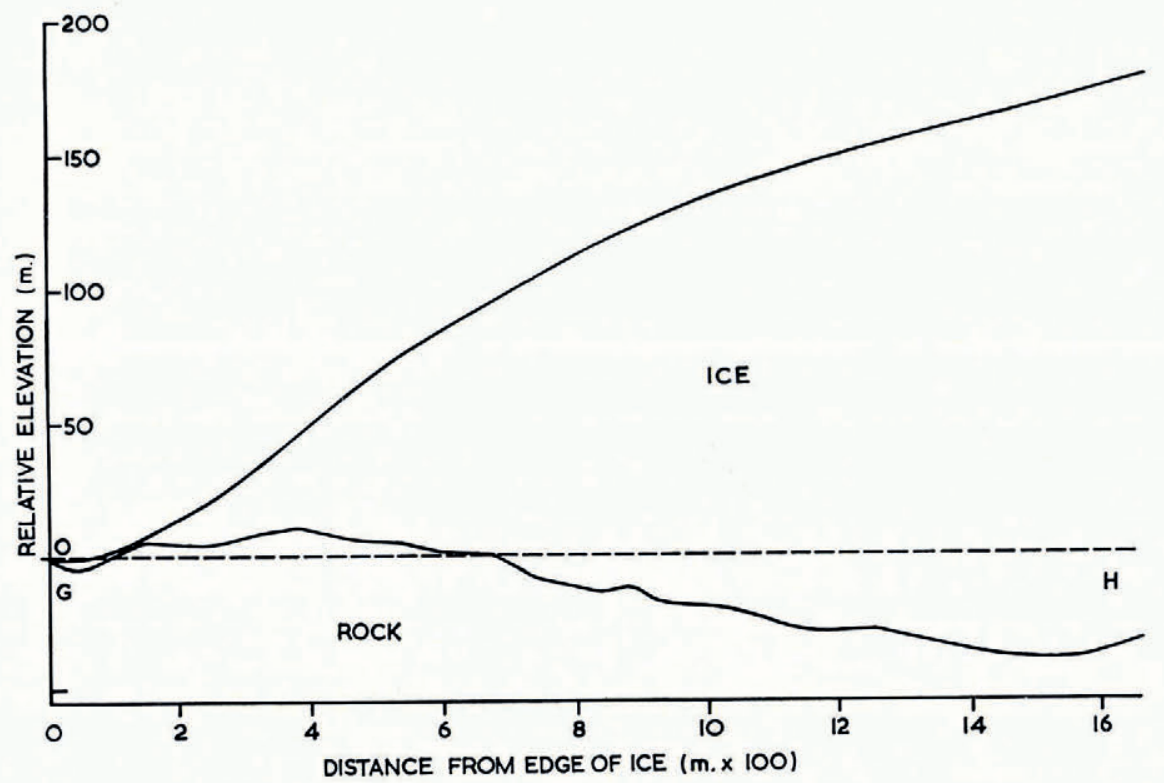

Fig. 3. Ice-cap edge detail immediately west of A (Fig. I) 
determined by the depth of ice at that station and to a lesser extent at the other stations, this iteration converges very rapidly. The Bouguer terrain-corrected anomaly and the final crosssection of the glacier are shown in Figure $4 *^{*}$ The area of the computed cross-section is approximately $0.5 \mathrm{~km} .{ }^{2}$.

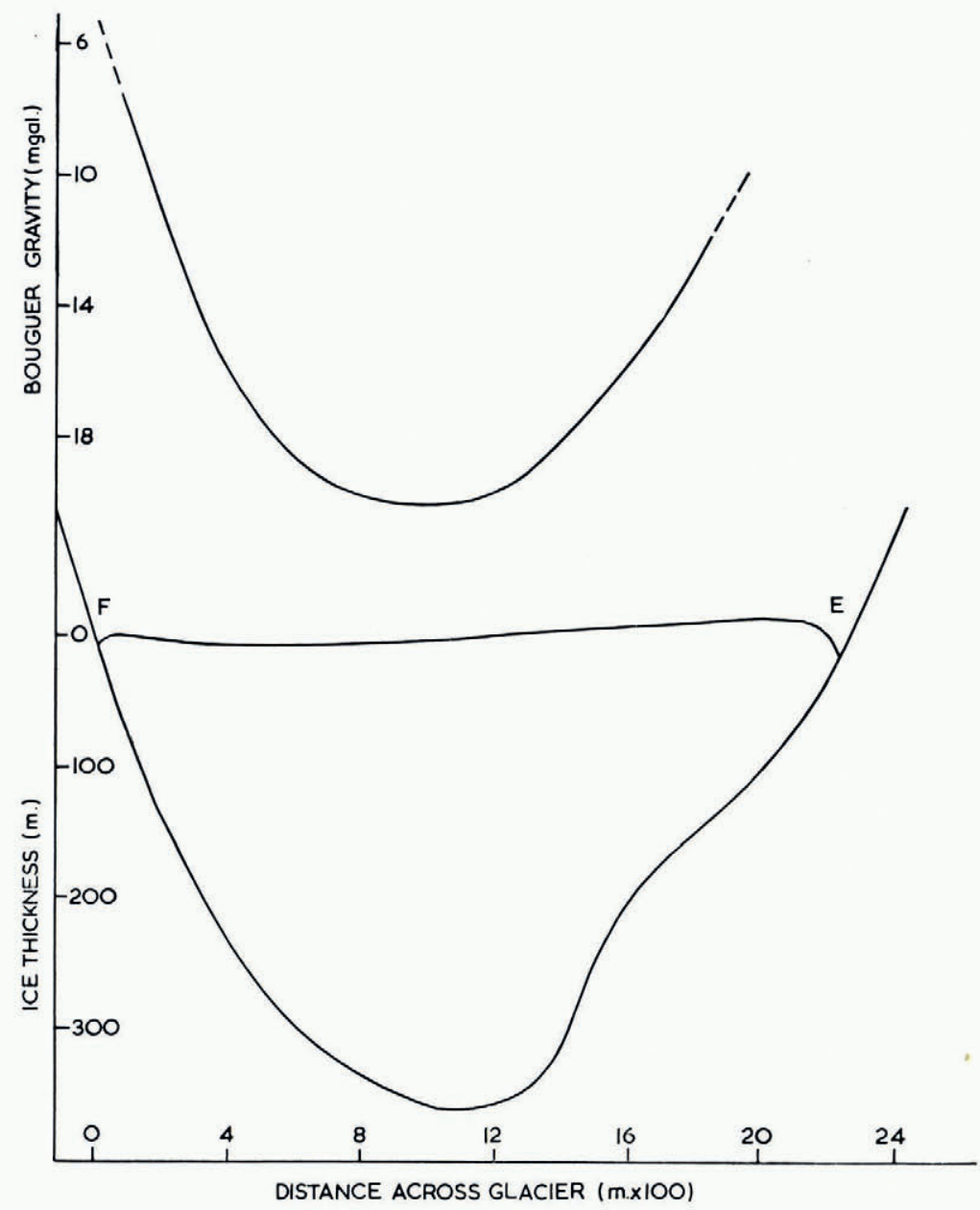

Fig. 4. Glacier Bouguer anomaly and depth profile

\section{Rock And Ice Densities}

On the north edge of the ice-cap traverse, the control stations lie on Precambrian metamorphic rocks of densities measured on seven moraine samples as $2.66 \pm 0.03 \mathrm{~g} . / \mathrm{cm} .^{3}$. Although these samples showed little evidence of weathering, rocks in situ may have a slightly higher density. Estimates by J. W. Cowie (personal communication) give sedimentary rocks occupying a region from a few kilometres from the north end of the traverse to about the ice-cap station and for the southern $20 \mathrm{~km}$. of the traverse. The remaining stations should lie

* The station locations, elevations, ice thicknesses and gravity values for all traverses are available from the Montreal office of the Arctic Institute of North America. 
over the Precambrian metamorphic rocks. The sedimentary rocks in the Croker Bay area consist of limestones, almost entirely replaced by dolomite to the north, and a small percentage of shale. For 80 per cent dolomite and 20 per cent shale, using the rock densities given by Dobrin (1960), the average density should be about $2 \cdot 65 \mathrm{~g} . / \mathrm{cm} .{ }^{3}$. An average value of $2.66 \mathrm{~g} . / \mathrm{cm} .^{3}$ has been used throughout the ice-cap traverse.

Seven samples from the Precambrian metamorphic rocks comprising the Sverdrup Glacier region gave an average density of $2.67 \mathrm{~g} . / \mathrm{cm} .{ }^{3}$ which has been used in the glacier profile.

Ice density measurements were made to a depth of io $\mathrm{m}$. at 8 locations above and below the firn line on the ice cap by R. Koerner (personal communication). Below the firn line or accumulation line where the surface ice may be expected to have come from some depth, densities averaged $0.90 \mathrm{~g} . / \mathrm{cm} .^{3}$. In the accumulation region near the centre of the ice cap the densities were very variable, because of the prevalence of ice layers in the firn, but average about $0.86 \mathrm{~g} . / \mathrm{cm} .^{3}$. This is only representative of the near-surface layers to a depth of perhaps roo $\mathrm{m}$. Geo-electric studies by Greenhouse (unpublished) have indicated an electrical conductivity contrast presumably due to the transition from firn to glacier ice at 60 to $80 \mathrm{~m}$. depth. It should be noted that surface measurements even below the firn line are representative of surface pressures only. At greater depths compression of the air bubbles within the ice could appreciably increase the density. A density of $0.9 \mathrm{I} \mathrm{g} . / \mathrm{cm} .{ }^{3}$ was used in the calculations for both the ice cap and the glacier.

\section{Estimates of Acguracy}

\section{Ice-cap profile}

The gravimeter readings are expected to be within $\pm \mathrm{I} \cdot \mathrm{o}$ mgal. across the ice cap, which implies an error in ice thickness of about $\pm 7 \mathrm{~m}$. for the stations near the centre of the traverse.

The corrections for latitude should introduce no more than $\pm 0 \cdot 0 \mathrm{mgal} . / \mathrm{km}$. of traverse or about $\pm 3 \mathrm{~m}$. in ice thickness at the centre.

The station elevations are probably a major source of error, which at $\pm 0 .{ }^{1} 5 \mathrm{~m} . / \mathrm{km}$. of traverse result in a Bouguer anomaly error of about $\pm 0.04 \mathrm{mgal} . / \mathrm{km}$. of traverse or $\pm \mathrm{I} 5 \mathrm{~m}$. in ice thickness at the centre.

The ice density of $0.9 \mathrm{I} \mathrm{g} . / \mathrm{cm} .^{3}$ should be within $\pm 0.0 \mathrm{I} \mathrm{g} . / \mathrm{cm} .{ }^{3}$ through the bulk of the ice cap. A consideration of a $100 \mathrm{~m}$. surface layer of low-density material, say $0.86 \mathrm{~g} . / \mathrm{cm} .^{3}$, results in an error of only about $0.2 \mathrm{mgal}$., so no correction has been attempted.

The rock densities in the areas of the traverse lying over the metamorphic rocks should be well within $\pm 0.02 \mathrm{~g} . / \mathrm{cm}^{3}$, although where sedimentary rocks may be expected to underlie the ice the error could be much larger with the chosen density of $2.66 \mathrm{~g} . / \mathrm{cm} .{ }^{3}$ probably too high. A reasonable limit is $2.5^{0} \mathrm{~g} . / \mathrm{cm}^{3}$. In the former areas, therefore, the error in density contrast should result in an error in ice thickness of \pm 2 per cent, while in the latter, particularly at the south end of the traverse, it could be \pm io per cent.

The change in regional gravity between the control stations at the north and south ends of the ice-cap traverse was found to be 14 mgal. There is some assurance that the gradient between these points is approximately constant in that the gradients between the control stations at the north end and between the control stations at the south end are in fair agreement with the implied overall gradient between north and south. Even so, this correction could easily result in an error of $\pm 2 \cdot 0$ mgal. at the centre of the traverse. This implies a thickness error at the centre of $\pm 25 \mathrm{~m}$.

The total error in the computed ice thickness from all these sources is about $\pm 60 \mathrm{~m}$. or I 5 per cent at the centre of the traverse. At the edges, particularly towards the north end, the error should be somewhat less.

On the detailed profile at the north edge of the ice cap the major source of error will lie 
in the station elevations: about $\pm 0.3 \mathrm{~m}$. in surface elevation per $\mathrm{i}$ oo $\mathrm{m}$. of traverse or about $\pm 0.08 \mathrm{mgal}$./ $100 \mathrm{~m}$. Terrain and latitude corrections, errors in density contrast and gravimeter error will all contribute small additional errors that should be less than $\pm 0 \cdot 07 \mathrm{mgal}$./ $100 \mathrm{~m}$. The total estimated error in computed ice thickness will then be $\pm 2.0 \mathrm{~m}$. $/ 100 \mathrm{~m}$. from the edge of the ice cap.

\section{Glacier}

The greatest error in the computed glacier profile results from the uncertainty in the terrain correction coupled with the fact that there are no stations off the glacier. The terrain corrections range from 7 mgal. at the most easterly station to $3 \mathrm{mgal}$. at the centre and western stations. The slope and height of the valley walls are fairly uniform and reasonably well defined so that these values should be within \pm 20 per cent. The uncertainty involved in estimating the Bouguer gravity values that would be expected off the glacier (about 6 mgal. from the edge stations) is difficult to determine but $\pm 2 \cdot 0$ mgal. is suggested as a reasonable limit. In comparison with these uncertainties, the remaining sources of error: elevation corrections, density contrast, latitudes and gravimeter readings, should be negligible. The computed thickness may thus be expected to be within \pm 20 per cent at the centre with a somewhat larger error toward the edges. A preliminary seismic result by J. R. Weber (personal communication), of the Dominion Observatory of Canada, approximately $850 \mathrm{~m}$. from the eastern edge of the glacier gives a depth of $362 \mathrm{~m}$. which is in good agreement with the gravity computed value of $35^{\circ} \mathrm{m}$. at this point.

\section{Discussion}

The ice-cap profile gives a good estimate of the ice thickness and surface shape of the western part of the Devon Island ice cap. Using the measured profiles, a very rough determination gives a volume of $\mathrm{I}, 500 \mathrm{~km} .^{3}$ of ice in the western part of the ice cap (west of a line joining Belcher Glacier and Croker Bay). The whole ice cap may be expected to contain about two to three times this volume, although nothing is known of the thicknesses in the eastern part.

There are several features immediately evident from the ice-cap profile. The ice cap has largely a rock core, the ice being generally less than $500 \mathrm{~m}$. thick. In particular, going east toward Belcher Glacier and the highest part of the ice cap, there is a sharp rise in the bedrock elevation. The topography of the ice cap can apparently be largely accounted for by bedrock topography. This is in contrast to some other medium-sized Arctic ice caps such as the Barnes Ice Cap on Baffin Island (Littlewood, I952), where the bedrock topography is relatively flat.

Near the north end of the traverse there is a deep valley in the bedrock of about $300 \mathrm{~m}$. depth and 6 to $8 \mathrm{~km}$. width. This is about io to $15 \mathrm{~km}$. from the start of the major tributary to Sverdrup Glacier so it may be expected to feed into it. The glacier channel must therefore extend a considerable distance into the ice cap.

The intent of the edge detail in giving a representative edge profile has probably not been completely realized because of the close proximity of the deep ice valley which may distort the ice-flow pattern. However, the profile should be useful for future comparisons to determine the nature of any advance or retreat of the ice cap.

The gravity measurements on Sverdrup Glacier should give a good indication of the shape and depth of the glacier. With additional information on the distribution of velocities in the ice, estimates should be possible for the total ice flow. The area of the cross-section is approximately $0.5 \mathrm{~km} .^{2}$. 


\section{AcKnowledgements}

The author is indebted to the Arctic Institute of North America who sponsored this work with partial financial support from the National Research Council of Canada. The loan of the gravimeter by the Department of Geophysics, University of British Columbia, is gratefully acknowledged. Thanks are also due to Lt. R. A. Tansey of the Royal Engineers, who undertook the majority of the surveying, Mr. J. Greenhouse, who organized and directed the geophysical programme of 1962 , and to the many others of the Devon Island Expedition who assisted in some way.

MS. received 7 Fuly 1964

\section{REFERENGES}

Dobrin, M. B. I96o. Introduction to geophysical prospecting. Second edition. New York, McGraw-Hill.

Greenhouse, J. P. Unpublished. The application of direct current resistivity prospecting methods to ice masses. [Thesis, University of British Columbia, 1963.]

Littlewood, C. A. I 952. Gravity measurements on the Barnes Icecap, Baffin Island. Arctic, Vol. 5, No. 2, p. I 18 -24. Russell, R. D., and others. I 96o. Gravity measurements on the Salmon Glacier and adjoining snow field, British Columbia, Canada, by R. D. Russell, J. A. Jacobs and F. S. Grant. Bulletin of the Geological Society of America, Vol. 71, No. 8, p. 1223-29.

Wyness, R. Unpublished. Report to the Arctic Institute of North America, I96r. 